\title{
Absolute Adsorption Isotherms for Ethylbenzene + n-Octane + Zeolite NaX System: Determination of the Activity Coefficients of the Adsorbed Phase
}

\author{
(C) 2021 Jakubov E.S. \\ A.N. Frumkin Institute of Physical Chemistry and Electrochemistry, Russian Academy of Sciences, Moscow, \\ Russia
}

Поступила в редакцию 23.12.2020 г.

DOI: $10.17308 /$ sorpchrom.2021.21/3476

Adsorption from solution of nonelectrolytes by microporous adsorbents such as zeolites is not only of practical interest. Because of the well-defined internal structure of zeolite, it can be a good model system which provides the possibility to measure absolute adsorption in a direct experiment. Such data may lead to a better understanding the properties of the liquid solution in the micropores. Whereas the excess adsorption isotherm can easily be measured, the exact determination of the absolute adsorption isotherm requires rather painstaking and time-consuming experiments. So the main problem is to convert excess adsorption data to the absolute adsorption isotherm.

Given this circumstance, we previously proposed a method to estimate the absolute adsorption isotherm of a binary solution on a microporous adsorbent. The method is based on the Dubinin-Radushkevich equation modified for adsorption from solutions. The equation gives the concentration dependence of absolute adsorption of solution and includes three non-fitting parameters: the absolute (limiting) adsorption values of the pure components, which are much easier to measure than the absolute adsorption isotherm of solution, and the value of the equilibrium concentration corresponding to the maximum excess adsorption.

The purpose of this work was to study the physicochemical characteristics of the adsorption phase based on the absolute adsorption data of the adsorption system ethylbenzene + n-octane + zeolite NaX. Excess adsorption isotherms were measured at temperatures $303.15,338.15$, and $363.15 \mathrm{~K}$ using the conventional static method. The limiting (absolute) adsorption values of pure components were measured using the pycnometric method. It is shown that the measured excess adsorption isotherms belong to type II according to the Schay and Nagy classification. This indicates strong adsorption of ethylbenzene in the entire concentration range. Absolute adsorption isotherms of the solution and the preferentially adsorbed component were calculated using the above method. These data made it possible to calculate for the adsorbed phase the excess volume of mixing, solution density and activity coefficients of the solution components. Based on the latter, the excess thermodynamic functions of mixing for the adsorption solution were calculated: free energy, entropy and enthalpy. The data obtained allow us to draw some conclusions about the adsorbed solution. The negative value of the excess volume of mixing indicates volume contraction. The adsorbed phase activity coefficients indicate a significant negative deviation from ideality, which means the dominance of intermolecular interaction between different molecules. This is also indicated by the negative value of the excess free energy of mixing.

Keywords: Adsorption from binary liquid solution, absolute and excess adsorption, limiting adsorption, adsorbed phase activity coefficients, zeolite $\mathrm{NaX}$, excess thermodynamic functions of mixing for adsorption solutions.

\section{Introduction}

The absolute adsorption isotherm is an essential function in the study of the adsorption phenomenon. The primary sources of valuable information about adsorption obtained by flow microcalorimetry, IR-, NMR-, EPRspectroscopy are all the adsorbed molecules, not only the excess molecules. During physical transitions, all molecules take part in the adsorption phase, and the same situation 
takes place during adsorption-induced deformation of solid adsorbents. It should be noted that models describing adsorption within the framework of statistical thermodynamics are also based on the assumption that all adsorbed molecules are included in the process. Since, as is well known, only the adsorption excess isotherm can be easily measured experimentally, the basic problem of converting the excess adsorption data to absolute adsorption arises. This very important problem is still unsolved in the general case nevertheless reports are scarce about it. Therefore, it is extremely relevant.

The novelty of our recent series of works, to which the present work belongs, is that in the particular case of excess adsorption isotherms from a binary solution on strictly microporous adsorbents (zeolites) belonging to type II according to the well-known SchayNagy classification [1] for calculation absolute adsorption isotherms it is sufficient to have the limiting adsorption values for pure components and the concentration value corresponding to the maximum excess adsorption.

In our previous paper [2], we studied the adsorption system cumene + n-octane + $\mathrm{NaX}$. In this paper we present the experimental data on excess adsorption and the calculated absolute adsorption isotherms for the system ethylbenzene + n-octane + zeolite $\mathrm{NaX}$ at $303.15,338.15$ and $363.15 \mathrm{~K}$. The choice of this adsorption system has been determined precisely by the fact that the excess adsorption isotherm belongs to the abovementioned type and thus satisfying the conditions on which the proposed method is based. In addition, the investigation of the specified adsorption system is of importance for such industrial processes as the adsorption removal of traces of aromatic compounds from liquid alkanes.

For the above-mentioned adsorption system, this paper presents for the first time the main thermodynamic characteristics of the adsorbed solution on the basis of the absolute adsorption isotherms, namely the activity coefficients, the excess thermodynamic functions of mixing, the excess volume of mixing and the average density.

\section{Calculation scheme}

For calculation of the absolute adsorption isotherm we used the following relations [2]

$$
n^{s}=n_{m 2}^{s}+\left(n_{m 1}^{s}-n_{m 2}^{s}\right) \exp \left(-k\left|\ln x_{1}\right|^{n}\right),
$$

here $n^{s}$ is the absolute adsorption isotherm for the solution, (in $\mathrm{mmol} / \mathrm{g}$ ); $n_{m 1}^{s}$ and $n_{m 2}^{s}$ are the limiting (absolute) adsorption values for pure components (also in $\mathrm{mmol} / \mathrm{g}$ ); $x_{1}$ is the equilibrium concentration of the component 1 in the bulk phase, (in mole fractions); $k$ and $n$ are constants that can be determined by formulas (2) and (3)

$$
\begin{aligned}
n & =\frac{x_{1 m} \ln x_{1 m}}{\left(1-x_{1 m}\right) \ln \left(1-x_{1 m}\right)} \\
k & =-\frac{\ln \left(1-x_{1 m}\right)}{\left(-\ln x_{1 m}\right)^{n}} .
\end{aligned}
$$

Here $x_{1 m}$ denotes the concentration corresponding to the maximum excess adsorption.

Using the well-known expression (4) relating the excess adsorption $n_{1}^{e}$ to the absolute adsorption of solution $n^{s}$ and the composition of the adsorbed phase $x_{1}^{s}$

$$
n_{1}^{e}=n^{s}\left(x_{1}^{s}-x_{1}\right)=n_{1}^{s}-n^{s} x_{1},
$$

we can calculate the absolute adsorption isotherms for the preferably adsorbed component $1, n_{1}^{s}$.

Thus, knowing the limiting adsorption values for pure components $n_{m 1}^{s}$ and $n_{m 2}^{s}$ (which should be determined in a separate experiment) and the concentration $x_{1 m}$ from the excess adsorption isotherm $n_{1}^{e}$, one can determine the constants $k$ и $n$ by formulas (2) and (3) and the absolute adsorption of binary solution $n^{s}$ by formula (1) and, finally, the absolute adsorption isotherm $n_{1}^{s}$ by the expression (4).

The absolute adsorption isotherms $n_{1}^{s}$ and $n^{s}$ allow us to determine the excess volume of mixing of the adsorbed solution $V^{E s}$ according to following formula 


$$
V^{E s}=\left(\frac{W_{0}}{n^{s}}\right)\left[1-\left(\frac{n_{1}^{s}}{n_{m 1}^{s}}+\frac{n_{2}^{s}}{n_{m 2}^{s}}\right)\right],
$$

where $W_{0}$ is the micropore volume (in $\mathrm{cm}^{3} / \mathrm{g}$ ). In addition, we can calculate the density of the adsorbed solution $\rho^{s}$ (in $\mathrm{mmol} / \mathrm{cm}^{3}$ ) by the following relation

$$
\rho^{s}=\frac{n^{s}}{W_{0}}
$$

where $n^{s}$ is the absolute adsorption isotherm of solution in $\mathrm{mmol} / \mathrm{g}$.

Further, based on the absolute adsorption isotherms, the activity coefficients $\gamma_{i}^{s}$ for the adsorbed phase can be calculated from the following well-known relations [3]

$$
\begin{gathered}
\ln \left(\gamma_{2}^{s}\right)=x_{1}^{s} \ln \left[\frac{\gamma_{2}^{s}}{\gamma_{1}^{s}}\right]-\int_{0}^{x_{1}^{s}} \ln \left[\frac{\gamma_{2}^{s}}{\gamma_{1}^{s}}\right] d x_{1}^{s}+ \\
\int_{0}^{x_{1}^{s}}\left[\frac{1}{n^{s}}-\left(\frac{x_{1}^{s}}{n_{m 1}^{s}}+\frac{\left(1-x_{1}^{s}\right.}{n_{m 2}^{s}}\right)\right] \frac{d \Phi}{R T} \\
\frac{\gamma_{2}^{s}}{\gamma_{1}^{s}}=\frac{x_{1}^{s} \gamma_{2}\left(1-x_{1}\right)}{x_{2}^{s} \gamma_{1} x_{1}} \exp \left[\frac{\Phi-\Phi_{1}}{n_{m 1}^{s} R T}-\frac{\Phi-\Phi_{2}}{n_{m 2}^{s} R T}\right],
\end{gathered}
$$

where $\gamma_{i}$ is the activity coefficient of component $i$ in the bulk solution of the composition $x_{i}$, the variable $\Phi$ is determined by the expression $\Phi=\Pi W_{0}$, where $\Pi$ is the three-dimensional analog of the surface pressure. The latter can be easily obtained from the molar volume $v_{m}^{s}=W_{0} / n^{s}$ of the adsorbed phase. A change in the value of $\Phi$ as a function of $x_{1}$, can be calculated by the numerical integration of the well-known equation

$$
\Delta \Phi=\Phi-\Phi_{2}=R T \int_{0}^{x_{1} \gamma_{1}}\left(n_{1}^{e} / x_{2} x_{1} \gamma_{1}\right) d\left(x_{1} \gamma_{1}\right)
$$

Here the lower limit of integration corresponds to the state characterized by the sorbent immersed in the pure component 2.

Knowledge of $\gamma_{i}^{s}$ allows one to calculate for the adsorbed solution the excess free energy of mixing $g^{E s}$, the entropy of mixing $s^{E s}$ and the enthalpy of mixing $h^{E s}$ according to the expressions

$$
\begin{gathered}
g^{E s}=R T \sum x_{i}^{s} \ln \gamma_{i}^{s}, \\
s^{E s}=-\left(\partial g^{E s} / \partial T\right)_{x_{i}^{s}}, \\
h^{E s}=g^{E s}-T\left(\partial g^{E s} / \partial T\right)_{x_{i}^{S}} .
\end{gathered}
$$

\section{Experimental}

The commercial granulated zeolite with binder $\mathrm{NaX}-3 \mathrm{M}$ (batch 16 , the diameter of granules $2-3.5 \mathrm{~mm}$, pore volume $0.280 \mathrm{~cm}^{3} / \mathrm{g}$, supplied by Grozny Petroleum Research Institute) has been used as received and reactivated by heating to $450^{\circ} \mathrm{C}$ for $8-10 \mathrm{~h}$ under vacuum. Ethylbenzene and n-octane, analytical grade, have been dried with molecular sieve $\mathrm{NaA}$ prior to use.

The excess adsorption isotherms have been determined by the improved static technique [4]. The main feature of this technique is that the experiment can be conducted with one sample of adsorbent over the whole concentration range and without access to air. The equilibrium mass fraction of the preferentially adsorbed component has been measured by a differential refractometer, the cuvettes of which form a single unit with the adsorption cell.

The limiting adsorption values have been measured by the pycnometric method $[5,6]$.

\section{Results and discussion}

The excess adsorption isotherms $n_{1}^{e}$ (in $\mathrm{mmol} / \mathrm{g}$ ) for the system ethylbenzene $+n$-octane+NaX have been determined at three temperatures: $303.15,338.15$ and $363.15 \mathrm{~K}$. The numerical data are presented in Table 1. The experimental results for $303.15 \mathrm{~K}$ are also shown in Figure 1 as a function of the square root of concentration of ethylbenzene $\sqrt{x_{1}}$, where $x_{1}$ is a mole fraction. The data are presented in this form for convenience of perception. As follows from Figure 1, the measured excess adsorption isotherms are very steep at the initial concentration region indicating very strong adsorption of the preferential component.

The limiting absolute adsorption of pure components $n_{m 1}^{s}$ and $n_{m 2}^{s}$ in $\mathrm{mmol} / \mathrm{g}$ at three temperatures are presented in Table 2 .

First of all, the isotherms have been smoothed out, and then by numerical differentiation of $n_{1}^{e}$ with respect to $x_{1}$ the derivatives have been found. By equating them to zero the concentration $x_{1 m}$ for which $n_{1}^{e}$ has 
Table 1. Excess adsorption isotherms for ethylbenzene (component 1$)+n$-octane $+\mathrm{NaX}$ system $\left(x_{1}\right.$, mole fraction; $\left.n_{1}^{e}, \mathrm{mmol} / \mathrm{g}\right)$.

\begin{tabular}{|c|c|c|c|c|c|}
\hline \multicolumn{2}{|c|}{$303.15 \mathrm{~K}$} & \multicolumn{2}{c|}{$338.15 \mathrm{~K}$} & \multicolumn{2}{c|}{$363.15 \mathrm{~K}$} \\
\hline$x_{1}$ & $n_{1}^{e}$ & $x_{1}$ & $n_{1}^{e}$ & $x_{1}$ & $n_{1}^{e}$ \\
\hline 0 & 0 & 0 & 0 & 0 & 0 \\
0.00053 & 0.825 & 0.00088 & 0.810 & 0.00115 & 0.799 \\
0.00069 & 1.025 & 0.00147 & 0.992 & 0.00210 & 0.966 \\
0.00085 & 1.219 & 0.00194 & 1.174 & 0.00293 & 1.132 \\
0.00124 & 1.409 & 0.00230 & 1.364 & 0.00402 & 1.292 \\
0.00170 & 1.573 & 0.00349 & 1.497 & 0.00509 & 1.429 \\
0.00246 & 1.727 & 0.00502 & 1.618 & 0.00708 & 1.530 \\
0.00727 & 1.860 & 0.01032 & 1.784 & 0.01240 & 1.639 \\
0.01166 & 1.937 & 0.01789 & 1.860 & 0.02006 & 1.766 \\
0.01955 & 1.986 & 0.04487 & 1.917 & 0.04652 & 1.843 \\
0.04286 & 2.014 & 0.06642 & 1.923 & 0.05694 & 1.861 \\
0.05363 & 2.019 & 0.07711 & 1.903 & 0.07828 & 1.849 \\
0.06458 & 2.016 & 0.09838 & 1.860 & 0.08821 & 1.834 \\
0.07539 & 1.993 & 0.11925 & 1.816 & 0.12008 & 1.777 \\
0.10690 & 1.903 & 0.16125 & 1.727 & 0.16248 & 1.692 \\
0.16019 & 1.777 & 0.21310 & 1.616 & 0.21426 & 1.581 \\
0.21207 & 1.671 & 0.26520 & 1.509 & 0.26639 & 1.467 \\
0.26397 & 1.556 & 1 & 0 & 1 & \\
1 & 0 & & & & 0 \\
\hline
\end{tabular}

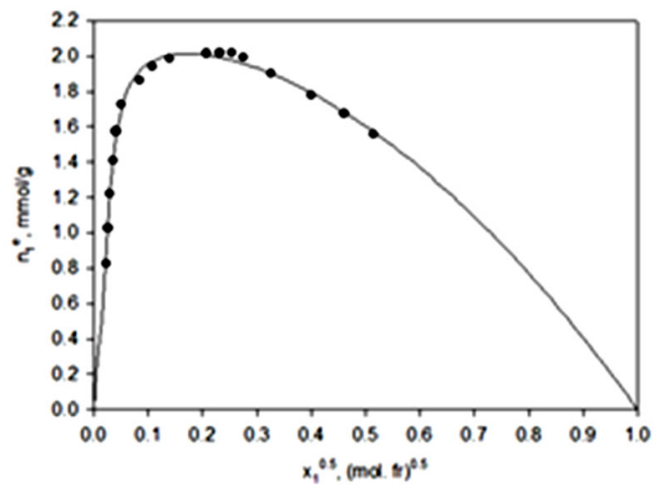

Fig. 1. Excess adsorption isotherms $n_{1}^{e}$ (in $\mathrm{mmol} / \mathrm{g}$ ) as a function of $\sqrt{x_{1}}$ ( $x_{1}$ is mole fraction) for the adsorption system studied at $303.15 \mathrm{~K}$.

Table 2. Limiting (absolute) adsorption of pure ethylbenzene (component 1 ) and $n$-octane in $\mathrm{NaX}$ zeolite.

\begin{tabular}{|c|c|c|}
\hline$T, \mathrm{~K}$ & $n_{m 1}^{s}, \mathrm{mmol} / \mathrm{g}$ & $n_{m 2}^{s}, \mathrm{mmol} / \mathrm{g}$ \\
\hline 303.15 & 2.366 & 1.602 \\
338.15 & 2.284 & 1.545 \\
363.15 & 2.216 & 1.505 \\
\hline
\end{tabular}

a maximum has been determined. Then the values of constants $n$ and $k$ have been calculated by formulae (2) and (3).Thus, the initial data obtained for calculation of the absolute adsorption isotherms are presented below: for $T=303.15 \mathrm{~K}$, $x_{1 m}=0.0319187, n=3.501041737$, $k=4.27111356 \times 10^{-4}$, $n_{m 1}^{s}=2.366 \mathrm{mmol} / \mathrm{g}, n_{m 2}^{s}=1.602 \mathrm{mmol} / \mathrm{g}$; 
Table 3. Excess adsorption isotherm $n_{1}^{e}$ (fitted values), the absolute adsorption isotherm of solution $n^{s}$, the absolute (individual) adsorption isotherm $n_{1}^{s}$ and the adsorbed phase equilibrium concentration of component $1 x_{1}^{s}$ at $338.15 \mathrm{~K}$ for the ethylbenzene $+n$-octane $+\mathrm{NaX}$ system.

\begin{tabular}{|c|c|c|c|c|}
\hline $\begin{array}{c}x_{1}, \text { mole } \\
\text { fraction }\end{array}$ & $\begin{array}{c}n_{1}^{e}, \mathrm{mmol} / \mathrm{g}, \\
\text { fitted }\end{array}$ & $n^{s}, \mathrm{mmol} / \mathrm{g}$ & $n_{1}^{s}, \mathrm{mmol} / \mathrm{g}$ & $\begin{array}{c}x_{1}^{s}, \text { mole } \\
\text { fraction }\end{array}$ \\
\hline 0 & 0 & 1.545 & 0 & 0 \\
0.00088 & 0.810 & 1.958 & 0.812 & 0.41475 \\
0.00147 & 0.992 & 2.014 & 0.995 & 0.49418 \\
0.00194 & 1.174 & 2.042 & 1.177 & 0.57653 \\
0.00230 & 1.364 & 2.060 & 1.369 & 0.66451 \\
0.00349 & 1.497 & 2.099 & 1.504 & 0.71652 \\
0.00502 & 1.618 & 2.131 & 1.629 & 0.76434 \\
0.01032 & 1.784 & 2.184 & 1.807 & 0.82714 \\
0.01789 & 1.860 & 2.216 & 1.900 & 0.85718 \\
0.04487 & 1.917 & 2.254 & 2.019 & 0.89557 \\
0.06642 & 1.893 & 2.264 & 2.043 & 0.90229 \\
0.07711 & 1.883 & 2.268 & 2.058 & 0.90759 \\
0.09838 & 1.849 & 2.272 & 2.073 & 0.91221 \\
0.11925 & 1.813 & 2.275 & 2.084 & 0.91596 \\
0.16125 & 1.734 & 2.278 & 2.101 & 0.92232 \\
0.21310 & 1.633 & 2.281 & 2.119 & 0.92896 \\
0.26520 & 1.528 & 2.282 & 2.133 & 0.93486 \\
1 & 0 & 2.284 & 2.284 & 1 \\
\hline
\end{tabular}

for $T=338.15 \mathrm{~K}$, $x_{1 m}=0.0427323, n=3.222658303$, $k=1.079137534 \times 10^{-3}$, $n_{m 1}^{s}=2.284 \mathrm{mmol} / \mathrm{g}, n_{m 2}^{s}=1.545 \mathrm{mmol} / \mathrm{g}$;

for $T=363.15 \mathrm{~K}$, $x_{1 m}=0.0509166, n=3.056741167$, $k=1.860741425 \times 10^{-3}$ $n_{m 1}^{s}=2.216 \mathrm{mmol} / \mathrm{g}, n_{m 2}^{s}=1.505 \mathrm{mmol} / \mathrm{g}$.

Based on these data, we can further calculate the absolute adsorption isotherms for the solution $n^{s}$ and for the preferably adsorbed phase $n_{1}^{s}$ by means of Eqs (1) and (4) respectively. Table 3 shows the complete set of these results for $T=338.15 \mathrm{~K}$ including the concentrations of the component 1 in the adsorbed phase $x_{1}^{s}=n_{1}^{s} / n^{s}$. Figure 2 shows the isotherm of the composition of the adsorbed solution $x_{1}^{s}$ as a function of the bulk solution composition at $T=303.15 \mathrm{~K}$. As can be seen from Figure 2 the isotherm is close to unity over a wide range of concentration.

Another quantity of interest is the excess volume of mixing of the adsorbed solution $V^{E s}$. Figure 3 shows the quantity $V^{E s}$ as a function of $x_{1}^{s}$ for $338.15 \mathrm{~K}$ calculated by means of Eq. (5). As can be seen from this figure the excess volume of mixing of the adsorbed phase reveals the negative deviation from additivity over the whole concentration range, indicating volume contraction. In addition, we have calculated the density of the adsorbed solution $\rho^{s}$ using Eq. (6). Figure 4 shows the concentration dependence of $\rho^{s}$ at three temperatures. The density of the adsorption phase is markedly lower than that of the bulk phase in almost the entire concentration range. Such a behavior of the adsorbed solution can be ascribed to the unfavorable ratio of sizes of the molecules in zeolite cavities. As for the temperature dependence of the density of the adsorption phase, this behavior is the same as in the bulk phase.

We can now proceed to calculate the activity coefficients for adsorbed phase by means of Eqs. (7) and (8). For this purpose we should first calculate the differential $d \Phi$ or $d\left(\Phi-\Phi_{2}\right)$ which by definition is given as 


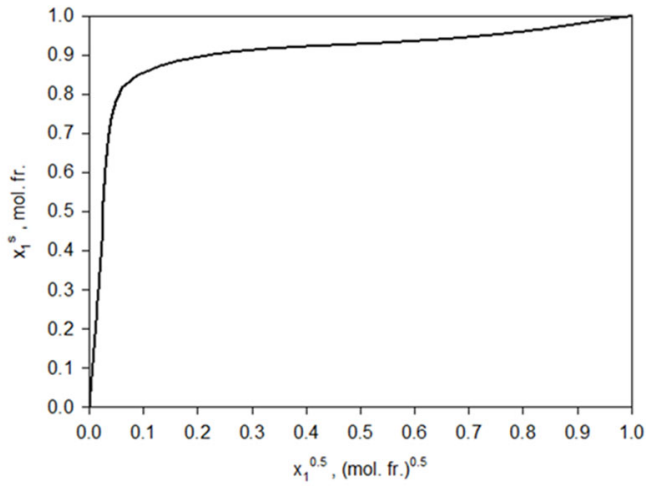

Fig. 2. Isotherm of the composition of the adsorbed solution $x_{1}^{s}$ as a function of $\sqrt{x_{1}}$ ( $x_{1}$ is mole fraction) for the adsorption system studied at $303.15 \mathrm{~K}$

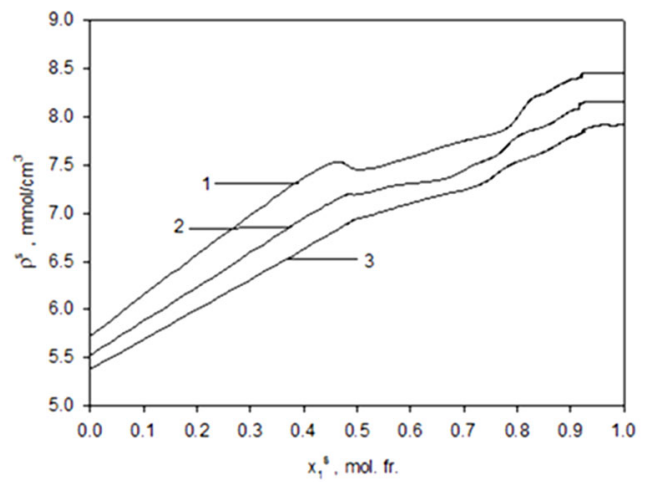

Fig. 4. Density of the adsorbed solution $\rho^{s}$ as a function of $x_{1}^{s}$ at $303.15,338.15$ and $363.15 \mathrm{~K}$

$$
d\left(\Phi-\Phi_{2}\right)=\frac{d\left(\Phi-\Phi_{2}\right)}{d x_{1}^{s}} \cdot d x_{1}^{s}
$$

where the derivative can be calculate by numerical differentiating.

The functions $\Phi-\Phi_{2}$ calculated by means of Eq. (9) at three temperatures are presented in Figure 5. As for the function $\Phi-\Phi_{1}$ in equation (8), it can be easily determined from the formula $\Phi-\Phi_{1}=$ $\left(\Phi-\Phi_{2}\right)-\left(\Phi_{1}-\Phi_{2}\right)$, where $\left(\Phi_{1}-\Phi_{2}\right)$ is equal to $\Phi-\Phi_{2}$ at concentration $x_{1}=1$.

It should be noted here that since the experimental bulk-phase activity coefficients $\gamma_{i}(i=1,2)$, which are a part of the integrand and also of Eq.(8), are not available, we used the liquid-vapor equilibrium data obtained on the basis of the generalized Guggenheim lattice theory [7]. The activity coefficients $\gamma_{i}^{s}$ of the adsorbed phase as a function of the

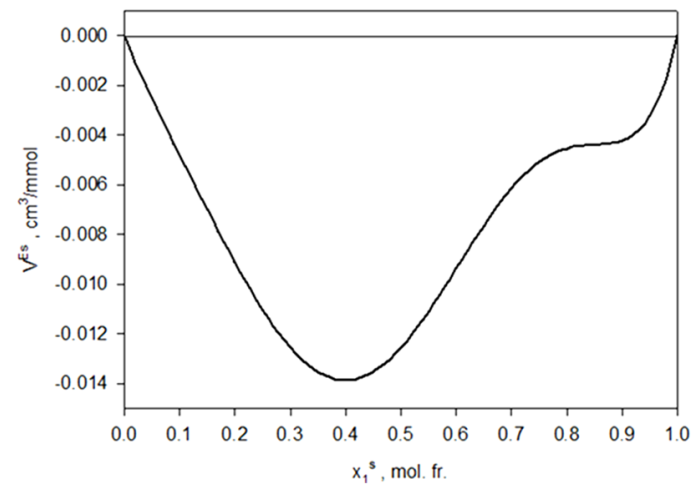

Fig. 3. Dependence of the excess volume of mixing of the adsorbed solution $V^{E s}$ on composition $x_{1}^{s}$ at $338.15 \mathrm{~K}$

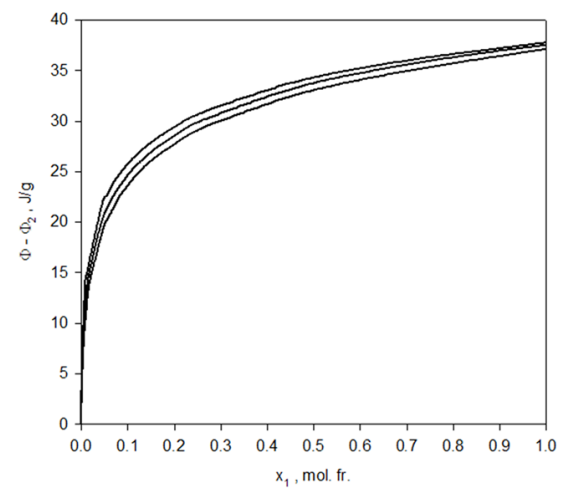

Fig. 5. Dependence of the change in the function $\Delta \Phi$ on composition $x_{1}$ at 303.15 , 338.15 and $363.15 \mathrm{~K}$

adsorbed phase mole fraction for $338.15 \mathrm{~K}$ are shown in Figure 6. They exhibit substantial negative deviation from ideality, which indicate that the molecular interactions between unlike molecules are dominant. The adsorbed phase activity coefficients for all three temperatures calculated by means of Eqs. (7) and (8) are summed up in Table 4.

Further, one of the important characteristics of solutions is the excess thermodynamic function of mixing. On the basis of the calculated adsorbed phase activity coefficients at three temperatures, we have determined the excess thermodynamic functions of mixing for the adsorbed phase by means of Eqs. (10), (11) and (12). The adsorbed phase concentration dependences of the excess free energy of mixing $g^{E s}$, the excess 


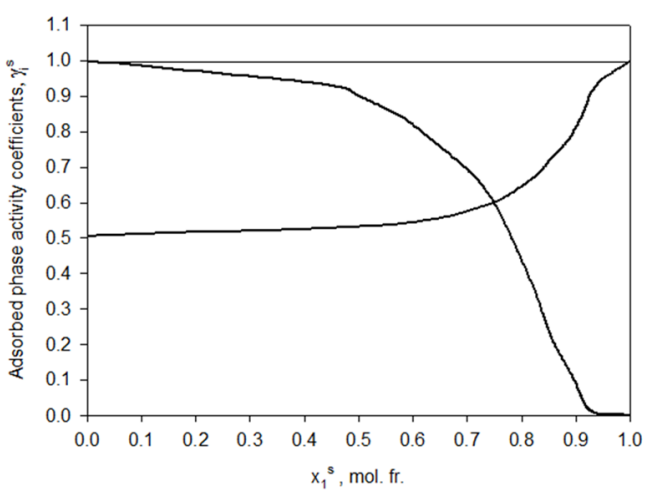

Fig. 6. Adsorbed phase activity coefficients $\gamma_{i}^{s}$ for the system studied at $338.15 \mathrm{~K}$

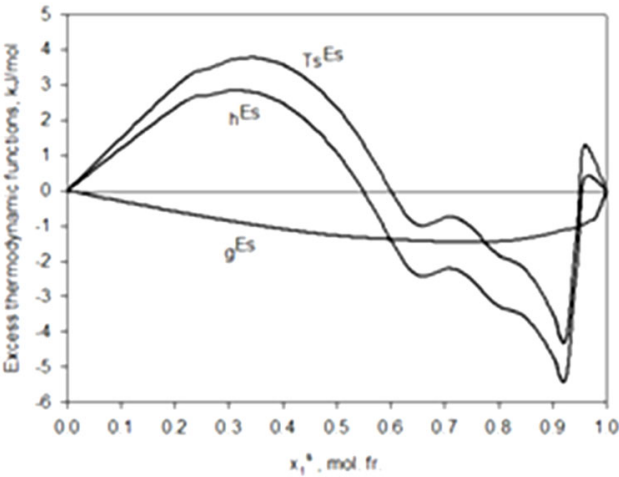

Fig. 7. Excess thermodynamic functions of mixing of the adsorbed solution as a function of $x_{1}^{s}$ at $363.15 \mathrm{~K}$.

Table 4. Adsorbed phase activity coefficients for the system ethylbenzene $+n$-octane $+\mathrm{NaX}$ at $303.15,338.15$ and $363.15 \mathrm{~K}$ based on the calculated individual absolute adsorption isotherms.

\begin{tabular}{|c|c|c|c|c|c|c|c|c|}
\hline \multicolumn{3}{|c|}{$303.15 \mathrm{~K}$} & \multicolumn{3}{|c|}{$338.15 \mathrm{~K}$} & \multicolumn{3}{|c|}{$363.15 \mathrm{~K}$} \\
\hline $\begin{array}{c}x_{1}^{s}, \\
\text { mol.fr. }\end{array}$ & $\gamma_{1}^{s}$ & $\gamma_{2}^{s}$ & $\begin{array}{c}x_{1}^{s}, \\
\text { mol.fr. }\end{array}$ & $\gamma_{1}^{s}$ & $\gamma_{2}^{s}$ & $\begin{array}{c}x_{1}^{s}, \\
\text { mol.fr. }\end{array}$ & $\gamma_{1}^{s}$ & $\gamma_{2}^{s}$ \\
\hline 0 & 0.8095 & 1 & 0 & & 1 & 0 & 0.3456 & 1 \\
\hline 0.40501 & 0.6261 & & 0.41475 & 0.5 & 0.9381 & 0.42987 & 0.4654 & 0.9075 \\
\hline 0.51542 & $\begin{array}{r}0.5761 \\
0.5650\end{array}$ & & 0.49418 & 0.5 & 0.8917 & 0.50264 & 0.5744 & 0.7432 \\
\hline 0.58678 & 0.5650 & & 0.57653 & & 0.8402 & 0.57878 & 0.6004 & 0.6867 \\
\hline 0.68179 & 0.5739 & & 0.66451 & 0.5 & 0.7316 & 0.65078 & 0.6149 & 0.6394 \\
\hline 0.73674 & 0.5955 & & 0.71652 & & 0.6689 & 0.71267 & 0.6254 & 0.6246 \\
\hline 0.78150 & & & 0.76434 & & 0.5565 & 0.75332 & 0.6452 & 0.5256 \\
\hline 0.84470 & & & 0.82714 & & 0.3397 & 0.79448 & 0.7174 & 0.3477 \\
\hline 0.86008 & $0.8 \mathrm{C}$ & & 0.85718 & & 0.2120 & 0.84955 & 0.7417 & 0.2699 \\
\hline 0.89669 & 0.92 & & 0.89557 & & 0.1042 & 0.89493 & 0.8056 & 0.1331 \\
\hline 0.90221 & 0.941 & & 0.91762 & & 0.0284 & 0.91046 & 0.8087 & 0.1187 \\
\hline 0.90652 & 0.9559 & 0 . & 0.91928 & & 0.0245 & 0.92204 & 0.8234 & 0.0877 \\
\hline 0.90978 & 0.9678 & 0286 & 0.92632 & & 0.0129 & 0.92381 & 0.8311 & 0.0759 \\
\hline 0.91608 & 0.9948 & 0.0188 & 0.94144 & & 0.0047 & 0.92727 & 0.8508 & 0.0511 \\
\hline 0.92207 & 1.0265 & 0.0112 & 0.95786 & & 0.0031 & 0.92897 & 0.8576 & 0.0333 \\
\hline 0.92591 & 1.0492 & 0.0077 & 0.97395 & 0.9669 & 0.0025 & 0.97191 & 0.8842 & 0.0034 \\
\hline 0.92927 & 1.0670 & 0.0056 & 1 & 1 & 0 & 1 & 1 & 0 \\
\hline
\end{tabular}

entropy of mixing $T \cdot s^{E s}$ and the excess enthalpy of mixing $h^{E s}$ at $363.15 \mathrm{~K}$ are shown in Fig. 7. This figure reveals that the excess free energy of mixing of the adsorbed solution is negative over the whole concentration range. In the case of bulk solutions, this points to the strengthening of interactions between different molecules. As for the excess entropy and enthalpy of mixing, their behavior is more complex: the curves have both negative and positive parts. Presumably, the positive parts of the excess entropy of mixing are due to the larger number of ways in which molecules of different sizes are arranged in the adsorption phase, compared to this number in the bulk phase.

\section{Conclusions}

The excess adsorption isotherms of ethylbenzene from solutions in $n$-octane in zeolite $\mathrm{NaX}$ and the absolute (limiting) adsorption values of the pure components have been measured at 303.15, 338.15 and 363.15 $\mathrm{K}$. The absolute adsorption isotherms for the system have been calculated using a non-fitting three parameter equation. On the basis 
of these data the main physico-chemical characteristics of the adsorbed solution have been calculated. Most notable are such properties as the excess volume of mixing, density, activity coefficients of the components

\section{References}

1. Schay G., in: Surface and Colloid Science (ed. E. Matijevic), Wiley-Interscience, New York, 1969, Vol. 2, p. 155.

2. Jakubov E.S., Protection of Metals and Physical Chemistry of Surfaces, 2019, Vol. 55, No 3, pp. 451-459.

3. Farhadpour F., Bono A., J. Colloid Interface Sci.,1988,Vol. 124, No 1, pp.209-227.

4. Shayusupova M.Sh., Cand. Sci (Chem) Dissertation, M., Institute of Physical Chemistry, Russ. Acad. Sci., 1979. 182 p. (in Russian) and excess thermodynamic functions of mixing.

The results obtained indicate that the absolute adsorption data give additional information about the adsorbed phase and lead to a better understanding of its properties.

5. Rakhmukov B.Kh., Seliverstova I.I., Serpinskii V.V., Fomkin A.A., Izv. Akad. Nauk SSSR, Ser. Khim, 1979, Vol. 28, No 11, pp. 2419-2422.

6. Yakubov E.S., Sorbtsionnye i Khromatograficheskiye protsessy, 2017, Vol. 17, No 4, pp. 56-573.

7. Kut'in A.M., Zorin A.D., Zh. Fiz. Chim., 1984, Vol. 58, pp. 596-602. (Russ. J. Phys. Chem.)

\title{
Изотермы абсолютной адсорбции для системы этилбензол + н-октан+ цеолит $\mathrm{NaX}$ : определение коэффициентов активности для адсорбционной фазы
}

\author{
(C) 2021 Якубов Э.С.
}

Институт физической химии и электрохимии им. А.Н. Фрумкина РАН, Москва

\begin{abstract}
Адсорбция из растворов неэлектролитов микропористыми адсорбентами, такими как цеолиты, представляет не только практический интерес. Благодаря четко определенной внутренней структуре цеолита, он может служить хорошей модельной системой, что дает возможность измерить абсолютную адсорбцию в прямом эксперименте. Такие данные могут привести к лучшему пониманию свойств жидкого раствора в микропорах. В то время как избыточная изотерма адсорбции может быть легко измерена, точное определение абсолютной изотермы адсорбции требует весьма кропотливого и трудоёмкого эксперимента. Поэтому основная проблема заключается в преобразовании данных по избыточной адсорбции в абсолютную изотерму адсорбции. Учитывая данное обстоятельство, нами ранее был предложен метод оценки изотермы абсолютной адсорбции бинарного раствора на микропористом адсорбенте. Метод основан на уравнении Дубинина-Радушкевича, модифицированном для адсорбции из растворов. Уравнение дает концентрационную зависимость абсолютной адсорбции раствора и включает три неподгоночных параметра: предельные величины адсорбции чистых компонентов, которые намного легче измерить, чем изотерму абсолютной адсорбции раствора, и значение равновесной концентрации, соответствующей максимальной избыточной адсорбции.

Целью данной работы было изучение физико-химических характеристик адсорбционной фазы на основе данных по абсолютной адсорбции адсорбционной системы этилбензол+н-октан+цеолит $\mathrm{NaX}$. Изотермы избыточной адсорбции измерены при температурах $303.15,338.15$ и 363.15 К с использованием общепринятого статического метода. Предельные (абсолютные) величины адсорбции чистых компонентов измерены пикнометрическим методом.

Показано, что измеренные избыточные изотермы адсорбции относятся к II типу по классификации Шая и Надя. Это указывает на сильную адсорбцию этилбензола во всей области концентраций.

Рассчитаны по указанному выше методу изотермы абсолютной адсорбции раствора и предпочтительно адсорбируемого компонента. Эти данные позволили рассчитать для адсорбционной фазы избыточный объем смешения, плотность раствора и коэффициенты активности компонентов раствора. На основе последних рассчитаны избыточные термодинамические функции смешения для адсорбционной фазы: свободная энергия, энтропия и энтальпия.
\end{abstract}


Полученные данные позволяют сделать некоторые выводы об адсорбционном растворе. Отрицательное значение величины избыточного объема смешения свидетельствует о сжатии объема. Коэффициенты активности указывают на значительное отрицательное отклонение от идеальности, что означает доминирование межмолекулярного взаимодействия между различными молекулами. Об этом же свидетельствует отрицательная величина избыточной свободной энергии смешения.

Ключевые слова: Адсорбция бинарного жидкого раствора, абсолютная и избыточная адсорбция, предельные величины адсорбции, коэффициентов активности компонентов адсорбционной фазы, цеолит $\mathrm{NaX}$, избыточные термодинамические функции смешения адсорбционного раствора.

Якубов Эдуард Сергеевич - к.х.н., доцент, старший научный сотрудник, Институт физической химии и электрохимии им. А.Н. Фрумкина РАН, Москва
Jakubov Eduard S. - Ph.D. (chemistry), associate prof., senior scientific worker, A.N. Frumkin Institute of Physical Chemistry and Electrochemistry, Russian Academy of Sciences, Moscow, email: edjakub@mail.ru 